\title{
Theoretical Analysis of Proton Therapy for Prostate Cancer
}

\author{
Buthainah Abdulmunem Ibrahim \\ Sciences College - Diyala University - Iraq \\ Received 25 May 2016; Accepted 25 September 2016
}

\begin{abstract}
$\underline{\text { Abstract }}$
The dependence of high proton energies has been investigated for proton therapy, which are governed by essential physical factors such as ion ranges and stopping powers. In addition, the volume of prostate is another variable factor varies according to human age and types of tumor. The aim of this theoretical study is about bombardment the prostate tumor by normal incidence protons from Medical Cyclotron at room temperature and energy ranges 60-250 MeV. It was studied by means of calculating Stopping Powers, 3D Ion ranges (longitudinal, lateral and radial) and the total target damage as a function of proton energies, which are calculated by TRIM computer code. The electronic stopping powers were calculated by Bethe-Bloch model, which have showed good coincidence with the TRIM results with 0.99 correlation factor. The ionization process is predominated through track of protons in tissues of the prostate, which yields a steep increase in total stopping power with penetration distance leading to the Bragg peak close to the end of range of the proton beams. The skewness and kurtosis are calculated, the negative sign of skewness for all spectra indicated that left tail (towards the surface of incidence protons) is larger than right (away from the surface) leading to reduce side effects to the neighboring normal tissues. The positive value of kurtosis means that the spectra are peaked. This indicates that the precise dose localization is delivered to the tissues. Proton therapy offers the benefit of specified dose localization and has favorable dose-depth distributions, compared with photon beam radiotherapy.
\end{abstract}




\section{Theoretical Analysis of Proton Therapy for Prostate Cancer}

\section{Buthainah Abdulmunem Ibrahim}

The angular distribution of protons with different energies are studied to reach the tumor in any position in prostate, it is noticed that at angle of 45 degree, there is equidimensional ion ranges. The total target damage increases with proton energies with values $(0.58$ - 1.7) $\mathrm{KeV} / \mathrm{ion}$ for ranges energy (60 - 250) MeV respectively. In order to reach the tumor, the proton beam direction could be changed in definite steps or turned on and off very quickly.Volumes of the different shapes of prostates change according to age and kinds of the tumor, which are prolate ellipsoid, prolate spheroid, or spherical shape. This leads to select the precise proton energy to prevent the spread of radiation outside the prostate.This theoretical study can be considered as a tool and an indication to determine the precise proton energy required for prostate cancer treatment to minimize the side effects. Proton therapy is a promising technology as a result of the rapid development of nuclear accelerators.

Keywords: proton Therapy - Cyclotron - Bragg Peak - Stopping Power - Ion Range Prostate Volume.

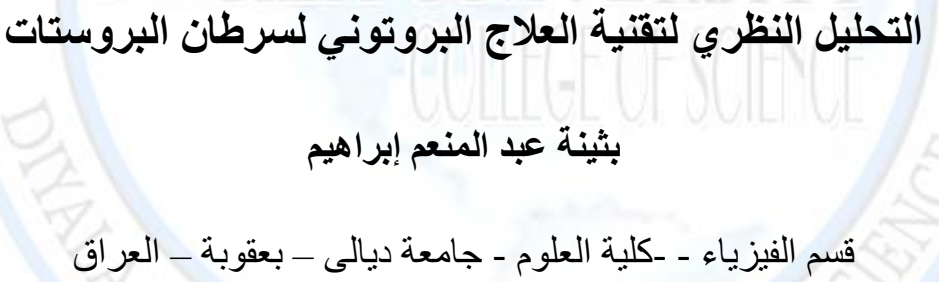

\section{الخلاصة}

تم التحقيق في اعتماد طاقات البروتون العالية في العلاج البروتوني، التي تحكمها عو امل فيزيائية أساسية مثل المدى الايوني وفدرة الايقاف، بالاضافة إلى ذلك حجم البروستات الذي يتغير تبعا إلى عمر الانسان ونوع الورم. ان هدف هذه الدراسة النظرية هو قصف ورم البروستات بو اسطة السقوط العمودي للبروتونات بو اسطة معجل السايكلوترون الطبي بطاقات تتراوح من 60 إلى 250 م.أف في درجة حرارة الغرفة. وتمت الدراسة بحساب قدرات الايقاف و المدى الايوني ثلاثي الابعاد (الطولي ، الافقي ، القطري) و الضرر الكلي للعينة كدالة لطاقة البروتونات باستخدام برنامج ترم ، وحسبت قدرة الايقاف الالكترونية باستخدام نموذج بيثــ بلو خ وقد اظهرت النتائج تو افقا جيدا مع برنامج ترم بعامل ارتباط 0.99. لقد هيمنت عملية التأين اثناء مسار البرونونات في انسجة البروستات ونتج عن ذلك زيادة حادة في قدرة الايقاف الكلية مما أدى إلى تكون قمة بر الك بالقرب من نهاية مدى حزمة البرونونات. وقد نم حساب الالتو اء و التفرطح حيث لوحظ الاشارة السالبة للالتو اء 


\title{
Theoretical Analysis of Proton Therapy for Prostate Cancer
}

\section{Buthainah Abdulmunem Ibrahim}

\begin{abstract}
لجميع الاطياف و هذا يعني ان الذيل الايسر للطيف (نحو سطح سقوط البرونونات) أكبر من الذيل الايمن (بعيدا عن السطح)

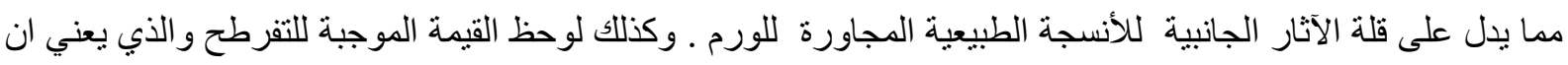
الاطياف ذات قم. ويدل ذلك على ايصال جرعة محددة في موقع النسيج. لذا فان العلاج البروتوني يقدم فو ائد اهمها الجرعة الدحددة في موقع النسيج وتوزيع جرعة مناسب في عمق النسيج وهذا ما يفضله على العلاج الفوتوني الاشعاعي. وقد تم در اسة التوزيع الز اوي للبرونونات بطاقات مختلفة لغرض الوصول إلى المكان المحدد للورم في البروستات ولوحظ بتساوي الابعاد الثلاثية للمدى الايوني عند سقوط البرونونات بزاوية 45 درجة .و ان الضرر الكلي للعينة (0.58 -1.7 ) كيلو الكترون فولت/ ايون يزداد عند الطاقات (60 - 250) مليون الكترون فولت على التو الي..و لغرض الوصول الى الورم يجب ان يتغير اتجاه حزمة البروتون في خطوات محددة أو تشغيلها وإيقافها بسر عة جدا.اثكالها اهليلجي ، كروي منطاول ، كروي ان معرفة حجم البروستات و التي تتغير حسب السن ونوع الورم و عادة تكون ، يؤدي إلى تحديد طاقة البروتونات المناسبة لمنع انتشار الإشعاع خارج البروستات. ويمكن اعتبار هذه الدراسة النظرية كأداة ومؤشرا لتحديد طاقة البروتون الدقيقة اللازمة لعلاج سرطان البروستات للحد من الآثار الجانبية. العلاج البرونوني هي تقنية واعدة نتيجة للتطور السريع في المعجلات النووية. الكلمات المفتاحية : العلاج البروتوني ـ السايكلوترون ـ قمة براك ـ قدرة الايقاف ـ المدى الايوني - حجم البروستات .
\end{abstract}

\section{Background}

Robert R. Wilson suggested in 1946, that energetic protons might be an effective treatment method [1], whilst he had been embroiled in the design of the Harvard Cyclotron Laboratory (HCL) [2]. Therapy by this technology were performed up till now, and showed very highly uses and give excellent results.

Therapy of proton uses ionized radiation. As protons are charged particles, a pencil proton beam can be exactly guided towards the tumor. Protons, heavy particles so they penetrate with minimal prevalence and they slow down comparatively fast when entering biological tissues. Due to their relatively large mass protons are located, and have slight transverse side dispersion in tissues; the beam is not widen frequently, stays focused on the tumor and transports lowdose to healthy tissues surrounded tumor. All protons of specified energy have certain range; few protons penetrate behind that distance. Moreover, proton beams offer the advantage of 


\section{Theoretical Analysis of Proton Therapy for Prostate Cancer}

\section{Buthainah Abdulmunem Ibrahim}

accurate dose localization and suitable dose-depth distributions, in comparison with photon radiotherapy in which neighboring tissues to tumor may receive similar dose and can be damaged. Proton beams have acute slope increment in energy deposition at Bragg peak [3] and transport few dose to the healthy tissues shortly after the Bragg peak location [4].

Accelerators are the main part used for proton therapy to produce protons for energy ranges (60 to 250 ) $\mathrm{MeV}$, so that deep-seated tumors in prostate in any depth can be treated [5]. The proton beam causes damage of the DNA cells within the tumor [5]. Adjusting proton energy during therapy maximizes killing tumors or stop reproduction of the cancerous cells. The development of medical accelerator technology started to produce innovative designs and compact, high frequency, linear accelerators in order to reduce their costs, permitting more proton therapy centers to be accessible to as many hospitals as possible [6].

Notably, LIGHT (Linac for Image Guided Hadrons Therapy) is developed accelerator for proper treatment of cancer tissues with proton therapy [7]. In addition, it also brings innovations in design and manufacturing to reduce production costs [8].

The essential physical factors such as stopping powers and ion ranges depend on the protons energy and properties of prostate tissues. In addition, the volume of prostate is another variable factor, which varies according to human age and types of tumor.

In this work, bombardment of the prostate tumor by normal incidence protons from Medical Cyclotron at room temperature and energy ranges $60-250 \mathrm{MeV}$. It was studied by means of calculating Stopping Powers, 3D Ion ranges (longitudinal, lateral and radial) and the total target damage as a function of proton energies, which are calculated by TRIM computer code [9] by using computer simulation for transport of protons in matter [10]. The electronic stopping powers were calculated by using Bethe-Bloch model, which have showed good agreement with the TRIM results with 0.99 correlation factor.

The projected proton ranges $(2.945 \mathrm{~cm}-36.257 \mathrm{~cm})$ with longitudinal straggles $(0.124-1.511)$ $\mathrm{cm}$ and lateral straggles $(0.076-0.853) \mathrm{cm}$ increased with proton energies $(60-250) \mathrm{MeV}$ respectively, in contrary to the energy losses ( $11.28-4.079) \mathrm{MeV} / \mathrm{cm}$ and the stopping powers $(10.84-3.923) \mathrm{KeV} /\left(\mathrm{mg} / \mathrm{cm}^{2}\right)$ decrease with increasing energy.The angular distribution of protons with different energies are studied to reach the tumor in any position in 


\section{Theoretical Analysis of Proton Therapy for Prostate Cancer \\ Buthainah Abdulmunem Ibrahim}

prostate, it is noticed that at angle of 45 degree, there is equidimensional ion ranges. The total target damage increases with proton energies with values $(0.58$ - 1.7) $\mathrm{KeV} / \mathrm{ion}$ for ranges energy (60 - 250) MeV respectively. In order to reach the tumor, the proton beam direction could be changed in definite steps or turned on and off very quickly.

Many studies were done for calculating the volume of prostate, some of them show that, the common shapes of human prostate are: prolate ellipsoid or prolate spheroid [11]

\section{Objective}

The aim of the study is to reduce the side effects to healthy tissues of proton therapy for prostate cancer. The selection of specific energy and direction of protons have protected the healthy tissues from radiation. This is also achieved through precise calculation of prostate volume.

\section{Theoretical Methods}

\section{Stopping power}

The ion is slowed down mainly by outer electrons of atoms of medium at high energy, and it moves nearly in a straight path. When the ion is slowed enough, the collision with the nucleus would be more probable. Finally, the nuclear stopping power was dominating the slowing down process [12]

The total stopping powers are equal to the energy loss $(E)$ per unit path length $(x)$, as shown by [13].

$$
S(E)=-N_{t} \frac{d E}{d x}
$$




\section{Theoretical Analysis of Proton Therapy for Prostate Cancer}

\section{Buthainah Abdulmunem Ibrahim}

Where,

$\frac{d E}{d x}$ - Energy loss.

$N_{t}$ - Atomic density (atom $/ \mathrm{cm}^{3}$ )

The total stopping power depends on the energy and type of the incident radiation and on the properties of the substance through which it passes. Since the production of an ion pair requires specific amount of energy, the ionization density is proportional to the total stopping power. Generally total stopping powers are increased toward the end of ion ranges and reached a maximum, the Bragg peak soon before the energy drops to zero. The curve that describes the stopping power versus the target depth is called the Bragg curve which represents major practical importance for proton therapy. Electronic energy loss has calculated by using Bethe formula given by [13]:

$$
\left.-\frac{d E}{d x}\right\rfloor_{e}=\frac{2 \pi Z_{1}^{2} e^{2}}{E} N Z_{2}\left(\frac{M_{1}}{m_{e}}\right) \ln \left(\frac{2 m_{e} v^{2}}{I_{o}}\right)
$$

Where,

E, $M_{1}, v-$ energy, mass and velocity of projectile respectively.

$\mathrm{N}$ - Atomic density of target.

$\mathrm{m}_{\mathrm{e}}, \mathrm{e}-$ mass and charge of the electron.

$\mathrm{Z}_{1}, \mathrm{Z}_{2}$ - the atomic number of the projectile and the target.

$I_{o}$-ionizing potential as function of $Z_{2}$, which is given [13] :

$$
I_{o}=\left\{\begin{array}{l}
12+\frac{7}{Z_{2}} \ldots \ldots \ldots \ldots\left(Z_{2}<13\right) \\
9.76+\frac{58.58}{Z_{2}{ }^{1.19}} \ldots \ldots \ldots \ldots\left(Z_{2} \geq 13\right)
\end{array}\right.
$$




\section{Theoretical Analysis of Proton Therapy for Prostate Cancer}

\section{Buthainah Abdulmunem Ibrahim}

$\therefore$ The electronic stopping power is:

$$
\left.S_{e}(E)=-\frac{1}{N} \frac{d E}{d x}\right\rfloor_{e}
$$

Nuclear stopping power based on ZBL (Ziegler, Biersack and Littmark ) interaction potential , which is

given by [13]:

$$
V(r)=\frac{1}{4 \pi \epsilon_{o}} \frac{z_{1} z_{2} e^{2}}{r} \emptyset(r / a)
$$

Where, $r$-the distance between the projectile and the target; $a_{1}$ is the so-called screening parameter which is

Given by:

$$
a_{1}=\frac{0.8854 a_{o}}{Z_{1}{ }^{0.23}+Z_{2}{ }^{0.23}}
$$

And the screening function is given by:

$\varnothing(x)=0.1818 e^{-3.2 x}+0.5088 e^{-0.9423 x}+0.2802 e^{-0.4029 x}+0.02817 e^{-0.2016 x}$

Where, $x=\frac{r}{a}$, and $a_{0}$ is the Bohr atomic radius $=0.529 \AA$.

Then, reduced nuclear stopping power is given by:

$$
S_{n}(\epsilon)=\frac{e}{\pi a^{2} \gamma \varepsilon_{o}} S_{n}(E)
$$

Where, $\gamma_{o}=\frac{4 M_{1} M_{2}}{\left(M_{1}+M_{2}\right)^{2}}$ 


\section{Theoretical Analysis of Proton Therapy for Prostate Cancer}

\section{Buthainah Abdulmunem Ibrahim}

For practical calculation, the ZBL universal nuclear stopping power for an ion energy $E_{o}$, which is given

By [13] :

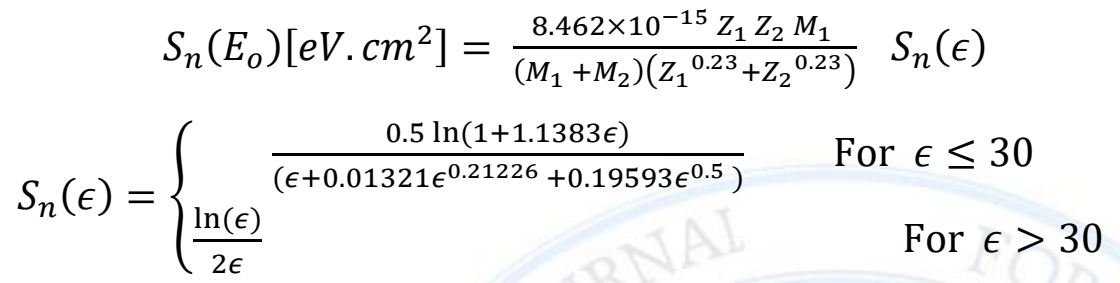

The reduced energy is given by:

$$
\epsilon=\frac{32.53 M_{2} E_{o}}{Z_{1} Z_{2}\left(M_{1}+M_{2}\right)\left(Z_{1}^{0.23}+Z_{2}{ }^{0.23}\right)}
$$

The total stopping power $\mathrm{S}(\mathrm{E})$ is given by [13]:

$$
\left.\therefore \frac{d E}{d x}\right|_{n}=N S_{n}(E)
$$

$S_{n}(E)$

$$
S(E)=S_{e}(E)+
$$

When the target is composed of more than one element, it is assumed that each component contributes to stopping power, for compound $A_{x} B_{y}$, where $\mathrm{x}+\mathrm{y}=1$, then the stopping power is given by the following equation :

$$
S_{A B}=x S_{A}+y S_{B}
$$

Where, $S_{A}$ and $S_{B}$ are the stopping powers of each target atom A and B respectively [13].

Theoretically simulation methods by computer to calculate the motion of ions in the material, are now the predominant way of treating stopping powers [14]. 


\section{Theoretical Analysis of Proton Therapy for Prostate Cancer \\ Buthainah Abdulmunem Ibrahim}

\section{Ion ranges}

The range, $\mathrm{R}$ of an energetic projectile with energy $E_{o}$ is determined by the rate of energy loss along the path of the projectile until stopping the projectile $\left(E_{o}=0\right)$ [13].

$$
R=\int_{E_{o}}^{0} \frac{d E}{d E / d x}=\int_{E_{o}}^{0} \frac{d E}{N S(E)}
$$

The general three dimensional ion ranges (Longitudinal, Lateral and Radial) are showed in figure (1).

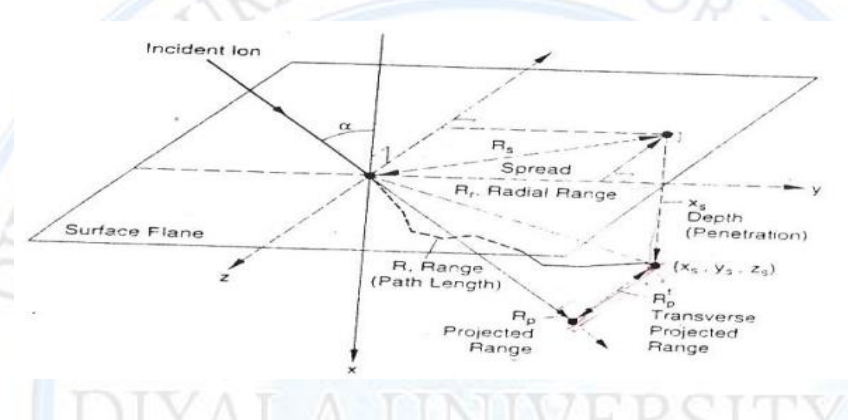

Figure (1): three dimensional ion ranges

Conventional methods used to compute ion ranges are based on the binary collision approximation (BCA) [10]. The well known BCA simulation program is, TRIM computer code based on the ZBL nuclear stopping and interatomic potential [9].

\section{Volume of prostate}

One of the factors that reduce side effects is the precise measuring of the prostate size to maintain healthy cells from radiation, that's why there are many studies about the prostate volume. Estimates of prostate volume for various scanning modalities have been used. Average gland sizes have calculated by the contoured ultrasound, ellipsoid ultrasound, and erMRI methods which are 33.99, 37.16, and $39.62 \mathrm{cc}$, respectively [15].

The relationship between age and human prostate size have been investigated in a population of men between the ages of 40 and 70 years to determine the normal prostate increase curve equation. The whole prostate volumes were measured by transrectal ultrasound (TRUS), these 


\section{Theoretical Analysis of Proton Therapy for Prostate Cancer}

\section{Buthainah Abdulmunem Ibrahim}

equations and models can facilitate further studies about prostate growth and may enable early diagnosis of benign prostate hyperplasia (BPH) [16]. The prostate volume has been estimated with transrectal ultrasound. Theoretically the volume is calculated by prolate ellipsoidal size formula [17] .The volume of the prostate was calculated by using TRUS. The height of the prostate is more precisely determined by using transaxial than mid sagittal scanning [18].Simple formula determined prostate volume (Prolate ellipsoid \& prolate spheroid), based on prostate diameters, the results provide only marginally inferior to planimetry, which are preferable because they are simpler to perform in the clinic and are associated with less inconvenience for patient [11].

\section{$\underline{\text { Results and Discussion }}$}

The elemental compositions of human prostate (W\&WJ were shown in table (1) ) [9]:

Table (1): Prostate elemental compositions

\begin{tabular}{|c|c|c|c|c|}
\hline Atom name & symbol & Atomic number & Atomic weight (amu) & Atomic percent \\
\hline Hydrogen & $\mathrm{H}$ & 1 & 1.008 & 64.32 \\
\hline Carbon & $\mathrm{C}$ & 6 & 12.011 & 4.57 \\
\hline Nitrogen & $\mathrm{N}$ & 7 & 14.007 & 1.10 \\
\hline Oxygen & $\mathrm{O}$ & 8 & 15.999 & 29.87 \\
\hline Sodium & $\mathrm{Na}$ & 11 & 22.99 & 0.05 \\
\hline Phosphorus & $\mathrm{P}$ & 15 & 30.974 & 0.02 \\
\hline Sulfur & $\mathrm{S}$ & 16 & 32.066 & 0.04 \\
\hline Potassium & $\mathrm{K}$ & 19 & 39.098 & 0.03 \\
\hline
\end{tabular}

Stopping powers have calculated by using TRIM computer code for proton ions in prostate. The electronic stopping powers are calculated from equation (2) and by using TRIM computer code, they showed good agreement with correlation factor 0.99 as shown in figure (3). 


\section{Theoretical Analysis of Proton Therapy for Prostate Cancer}

\section{Buthainah Abdulmunem Ibrahim}

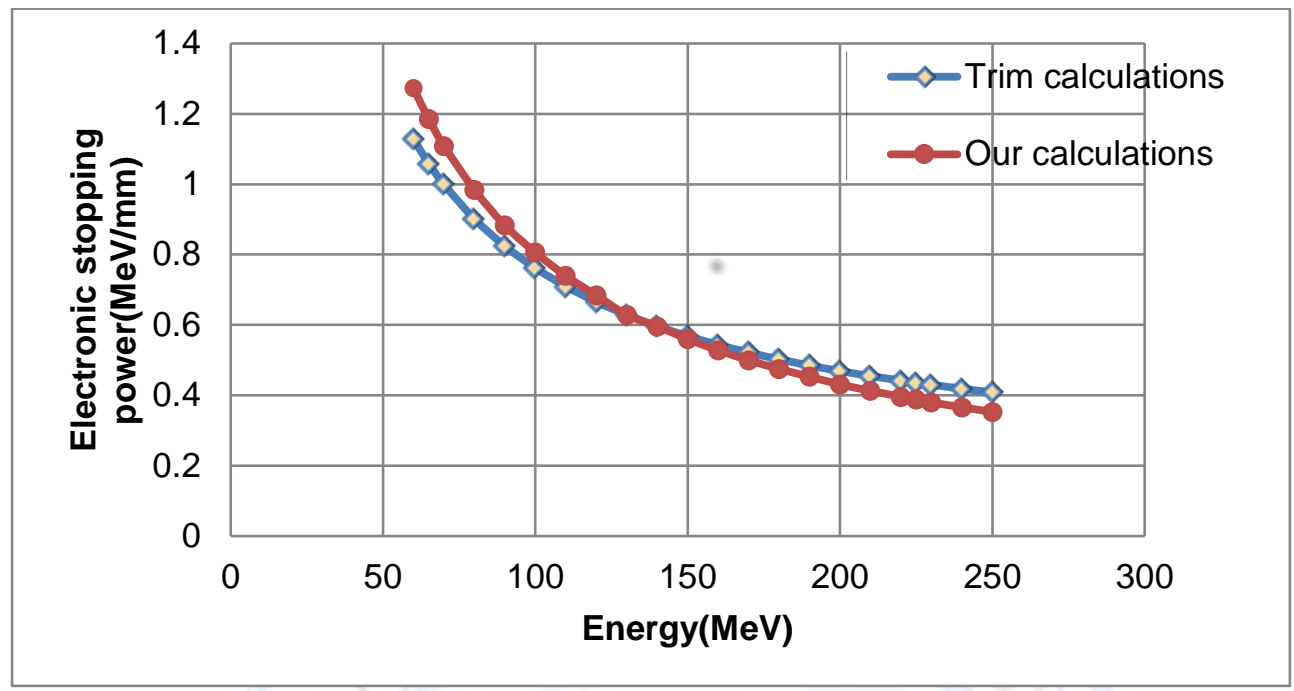

Figure (3): electronic stopping power versus proton energy

The skewness and kurtosis are calculated of the Bragg curves for vertical trajectory protons of different energies for bombarding prostate as shown in figure(4), the negative sign of skewness for all spectra indicate that left tail (towards the surface of incidence protons) is larger than right (away from the surface) leading to reduce side effects to the neighboring normal tissues. The positive value of kurtosis means that the spectra are peaked. This indicates that the precise dose localization deliver to the tissues. 


\section{DIYALA JOURNAL FOR PURE SCIENCES}

Theoretical Analysis of Proton Therapy for Prostate Cancer Buthainah Abdulmunem Ibrahim

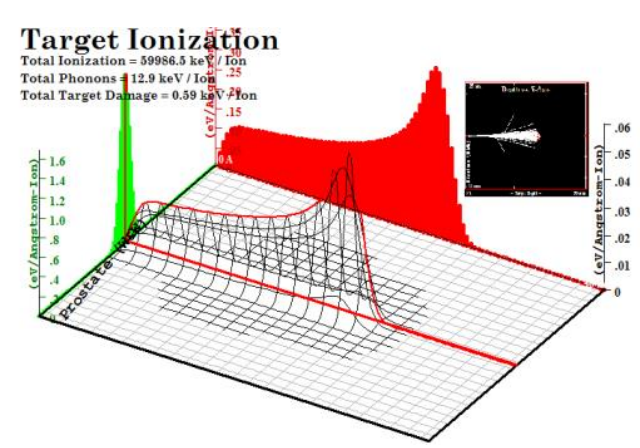

$60 \mathrm{MeV}($ depth $=2.95 \mathrm{~cm})$

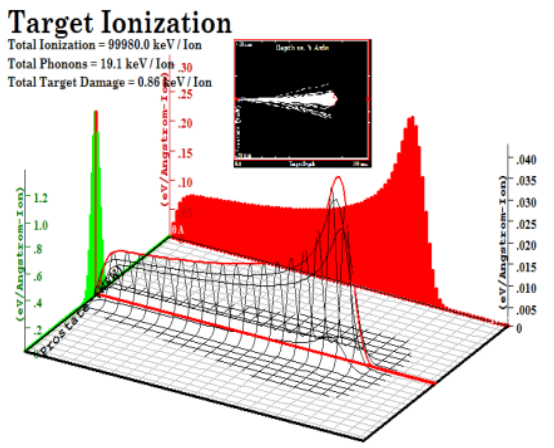

$100 \mathrm{MeV}($ depth $=7.37 \mathrm{~cm})$

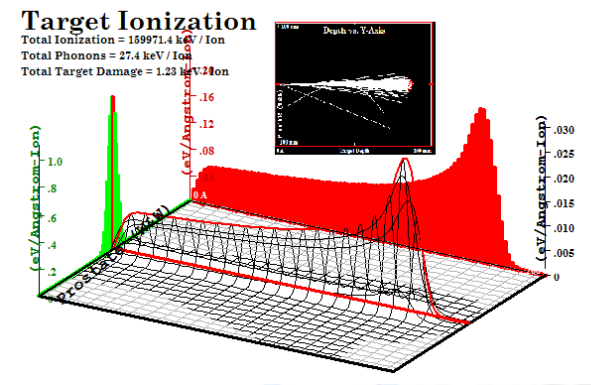

$160 \mathrm{MeV}($ depth $=16.8 \mathrm{~cm})$

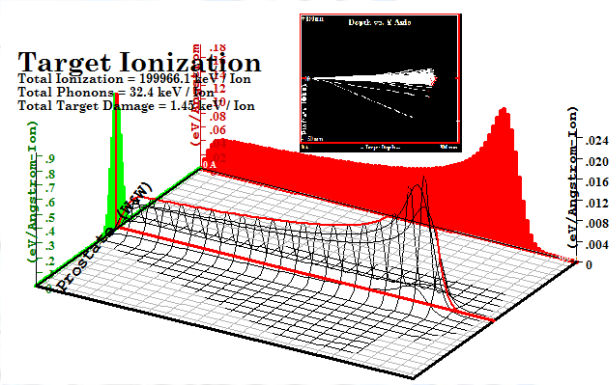

$200 \mathrm{MeV}($ depth $=24.8 \mathrm{~cm})$

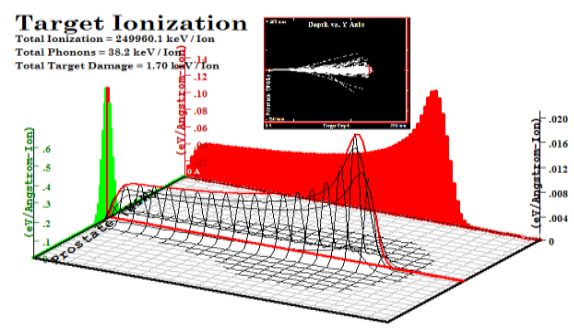

$250 \mathrm{MeV}(\operatorname{depth}=36.3 \mathrm{~cm})$

Figure (4): Bragg effect for different proton energies on prostate

The total target (prostate) damage increases as proton energy increases as shown in figure (5). 
Theoretical Analysis of Proton Therapy for Prostate Cancer

\section{Buthainah Abdulmunem Ibrahim}

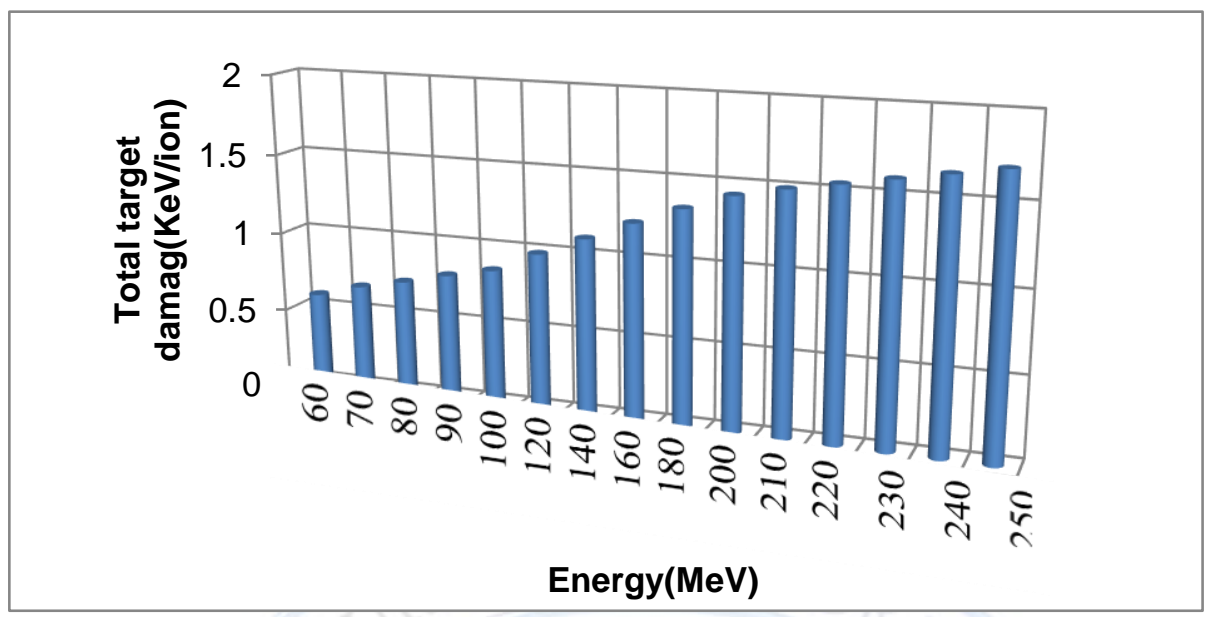

Figure (5): Total prostate damage versus proton energy

The proton ranges are calculated for bombardment the prostate tumor by vertical incidence protons from Medical accelerator at room temperature and energy ranges (60-250) MeV. $3 \mathrm{D}$ proton ranges (longitudinal, lateral and radial) are calculated with different proton energies, as shown in figure(6).

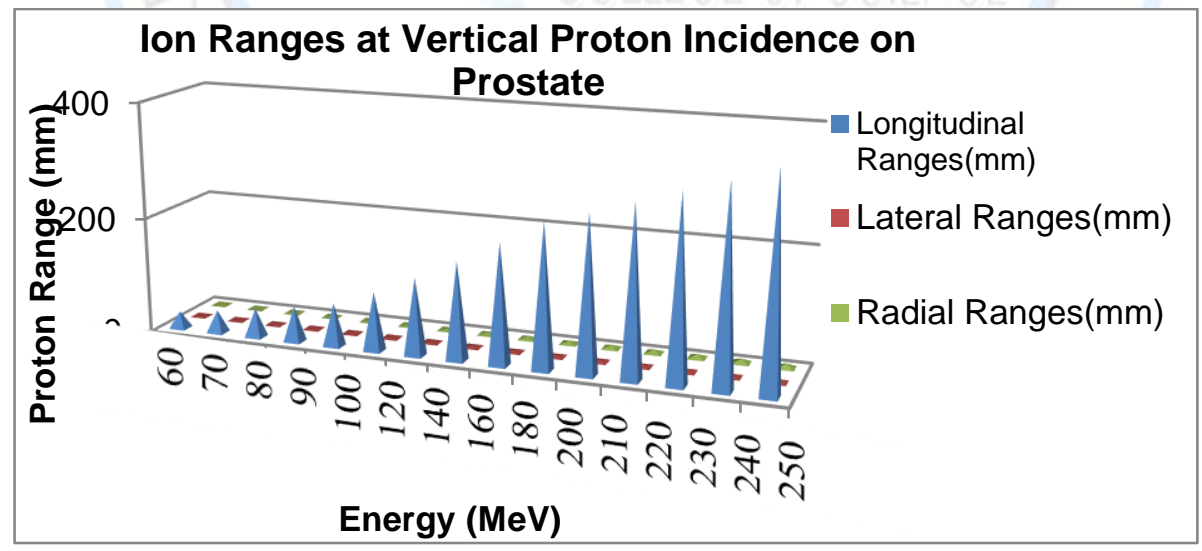

Figure (6): Three dimensional ranges versus energy at vertical proton incidence

At specific energy, the angular distributions of 3D proton ranges are taken for different angles $(0-90)^{o}$ with vertical on the prostate surface. The results show that equidimensional proton 


\section{DIYALA JOURNAL FOR PURE SCIENCES}

Theoretical Analysis of Proton Therapy for Prostate Cancer

Buthainah Abdulmunem Ibrahim

ranges at $45^{\circ}$ as shown in figure (7). For other angles larger than zero, there are equidimensional lateral and radial ranges only, illustrated in figure (8).

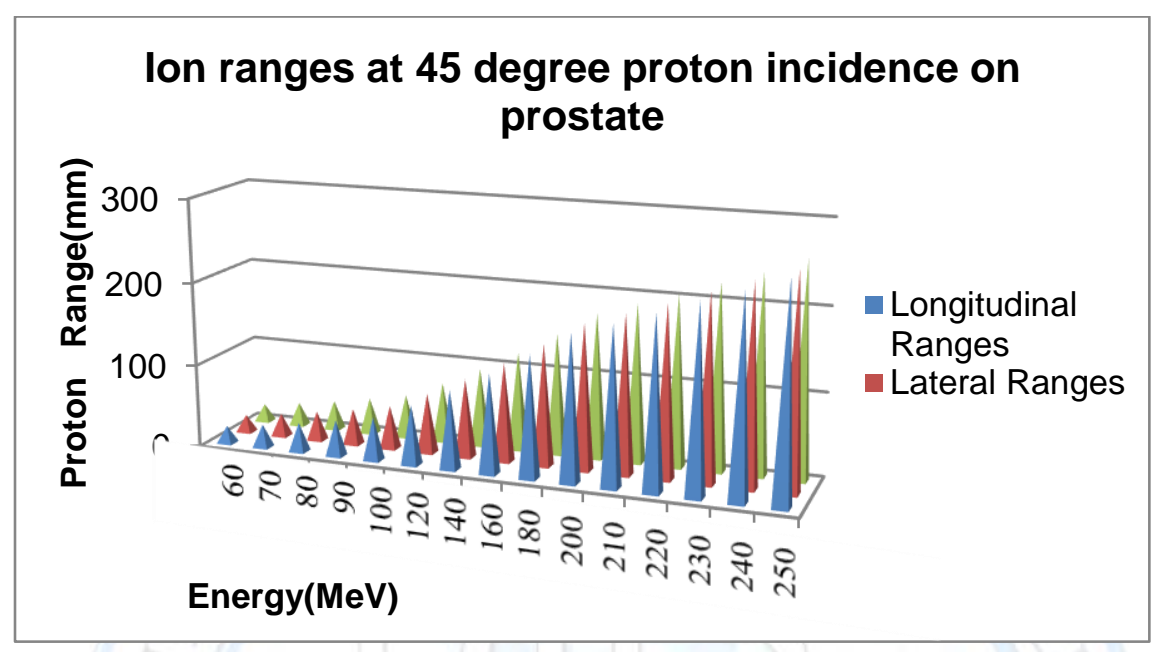

Figure (7): Three dimensional ranges versus energy at proton incidence angle $\mathbf{4 5}^{\circ}$

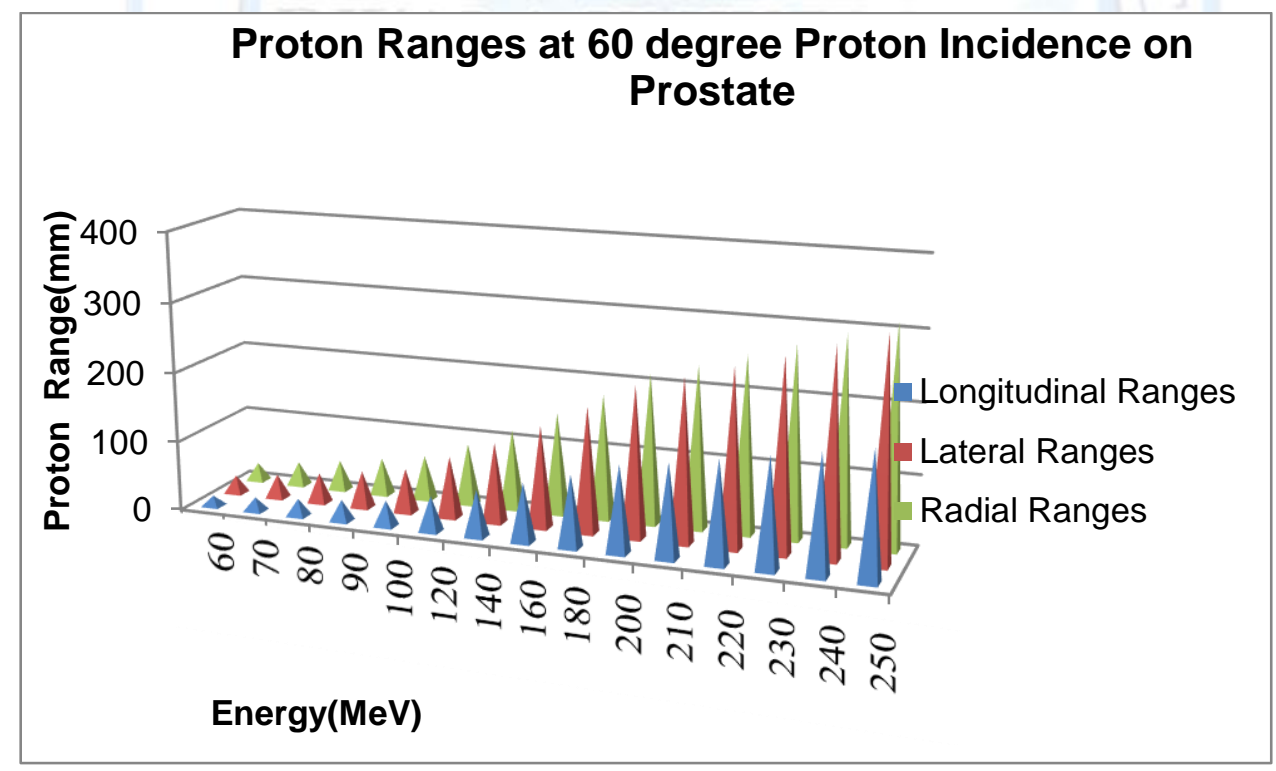

Figure (8): Three dimensional ranges versus energy at proton incidence angle $60^{\circ}$ 


\section{Theoretical Analysis of Proton Therapy for Prostate Cancer}

\section{Buthainah Abdulmunem Ibrahim}

\section{Conclusions}

The conclusions of this study have indicated that, the ranges of proton ions in prostate tissues were increased with increasing proton energies. As well as, the total damage of the prostate increased due to increase the proton energy.

Bragg effect means that, few side effects transferred to the neighboring vital tissues. High accuracy in calculating the size of the prostate have led to select the appropriate energy of proton beams and their directions according to the depth of tumors, which keep the radiation within the prostate volume to reduce the side effects to the healthy cells.

The angular distribution of proton beams leads to decrease the longitudinal ranges (depths of tumor) with increasing the angle of proton incidence. On contrary, lateral and radial ion ranges (area of tumor) was increased, so that the protons direction could be changed at definite steps, in order to reach the tumors in any position.

The vertical incidence of proton beams with high energy treat the distal depth tumors in prostate tissues, but the angular distribution of the proton beams treat the near depth tumors to the prostate surface.

This theoretical study can be considered as a tool and an indication to select the precise proton energy required for prostate cancer treatment and to minimize the side effects. Proton therapy is a promised technology as a result of the fast development of particle accelerators. 


\section{Theoretical Analysis of Proton Therapy for Prostate Cancer}

\section{Buthainah Abdulmunem Ibrahim}

\section{$\underline{\text { References }}$}

1. R. Wilson (1946), Radiological Use of Fast Protons, Radiology 47, 487- 491.

2. L. E. Williams (2004)., A Brief History of Harvard University Cyclotrons, American Journal of Roentgenology 183(6), 1558 - 1558 (2004).

3. H. Paganetti, T. Bortfeld (2005)., Proton Beam Radiotherapy - The State of the Art. in: New Technologies in Radiation Oncology (Medical Radiology Series),(Eds.) W.

Schlegel, T. Bortfeld and A.-L. Grosu, Springer Verlag, Heidelberg, ISBN, 3-540.

4. J. Metz (2002), Reduced normal tissue toxicity with proton therapy. Proton Info Web site: http://protoninfo. Com /Articles / University of Pennsylvania pdf. Published April, 28.

5. O. Jäkel (2007), State of the art in hadron therapy. In NUCLEAR PHYSICS METHODS AND ACCELERATORS IN BIOLOGY AND MEDICINE: Fourth International Summer School on Nuclear Physics Methods and Accelerators in Biology and Medicine, 958(1), 70-77.

6. E. Pedroni (2000), Latest developments in proton therapy. In Proceedings of EPAC, $240-244$.

7. U. Amaldi, R. Bonomi, S. Braccini, M. Crescenti, A. Degiovanni, M. Garlasché \& R. Zennaro (2010), Accelerators for hadron therapy: from Lawrence cyclotrons to linacs. Nuclear Instruments and Methods in Physics Research Section A: Accelerators, Spectrometers, Detectors and Associated Equipment 620(2), 563-577.

8. A. Lomax (1999), Intensity modulation methods for proton radiotherapy, Physics in medicine and biology 44(1), 185.

9. J. F. Ziegler (1985), J. P. Biersack and U. Littmark, The Stopping and Range of Ions in Matter, New York, Pergamon.

10. M. T. Robinson, I. M. Torrens (1974), Computer simulation of atomic - displacement cascades in solids in the binary- collision approximation, Physical Review B 9 (12), 5008 . 


\section{Theoretical Analysis of Proton Therapy for Prostate Cancer}

\section{Buthainah Abdulmunem Ibrahim}

11. L. M. Eri, H. Thomassen, B. Brennhovd, \& L.L. Håheim (2002), Accuracy and repeatability of prostate volume measurements by transrectal ultrasound. Prostate cancer and prostatic diseases 5(4), 273-278.

12. K. Nordlund, N. Runeberg \& D. Sundholm (1997), Repulsive interatomic potentials calculated using Hartree-Fock and density-functional theory methods. Nuclear Instruments and Methods in Physics Research Section B: Beam Interactions with Materials and Atoms 132(1), 45-54.

13. M., J. Nastasi, W. Mayer, J.K. Hirvonen (2003), Ion-Solid Interaction: Fundamentals and Applications, Cambridge University Press.

14. J. P. Biersack, L. G. Haggmark (1980), Monte Carlo Computer Program for transport of energetic ions in amorphous targets. Nuclear Instruments and Methods 174(1), 257 269.

15. Y. R. Murciano-Goroff, L. D. Wolfsberger, A. Parekh, F. M Fennessy, K. Tuncali, P. F. Orio, \& P. L. Nguyen (2014), Variability in MRI vs. ultrasound measures of prostate volume and its impact on treatment recommendations for favorable-risk prostate cancer patients: a case series, Radiation Oncology 9(1), 200.

16. S. J. Zhang, H. N. Qian, Y. Zhao, K. Sun, H. Q. Wang, G. Q. Liang \& Z. Li (2013), Relationship between age and prostate size. Asian journal of andrology 15(1), 116.

17. T., T. Marchie, V. C. Onuora (2006), Determination of normal range of ultrasonic sizes of prostate in our local environment. West African Journal of Radiology 8(1), 5464.

18. S. B. Park, J. K. Kim, S. H. Choi, H. N. Noh, E. K. Ji \& K. S. Cho (2000), Prostate volume measurement by TRUS using heights obtained by transaxial and midsagittal scanning: comparison with specimen volume following radical prostatectomy. Korean Journal of Radiology 1(2), 110-113. 